\title{
Predation on black flies (Diptera: Simuliidae) by the carnivorous plant Pinguicula vulgaris (Lentibulariaceae) in northern Sweden
}

\author{
Peter H. Adler \& Björn Malmqvist
}

Adler, P. H. \& Malmqvist, B. 2004: Predation on black flies (Diptera: Simuliidae) by the carnivorous plant Pinguicula vulgaris (Lentibulariaceae) in northern Sweden. - Entomol. Fennica 15: 124-128.

Adult back flies represented nearly $85 \%$ of 915 arthropods captured by the carnivorous plant Pinguicula vulgaris L. along a stream in northern Sweden. Two species, Cnephia eremites Shewell and Cnephia pallipes (Fries), accounted for more than $97 \%$ of the total number of captured black flies. By virtue of their large populations, site fidelity at lake outfalls, and concentrated activity near the ground, these flies provide a predictable supply of prey that could affect the fitness of streamside carnivorous plants.

Peter H. Adler, Department of Entomology, Soils, \& Plant Sciences, Clemson University, Clemson, SC 29634-0315 U.S.A.; E-mail: padler@clemson.edu Björn Malmqvist, Department of Ecology and Environmental Science, Umeå University, SE-90187 Umeå, Sweden; E-mail: bjorn.malmqvist@eg.umu.se

Received 7 November 2003, accepted 17 May 2004

\section{Introduction}

The boreal region encompasses a circumpolar area of about $11 \%$ of the Earth's land surface (Bonan \& Shugart 1989). Within this region, the immature stages of black flies typically dominate the aquatic ecosystem, with populations of some species reaching densities of 600,000 larvae $/ \mathrm{m}^{2}$ (Wotton et al. 1998). A significant part of this massive secondary production is transferred to the terrestrial environment as winged adults. The impacts of adult black flies on the terrestrial ecosystem have been interpreted largely in terms of the nuisance and biting habits of the females, which derive from the need for homeothermic blood to mature the eggs, and the transmission of blood-borne agents of disease. Poorly explored in the terrestrial ecosystem is the role of adult black flies as plant pollinators and insectivore prey
(Malmqvist et al. 2004). Nonetheless, lengthy lists of predators on black flies, both immatures and adults, have been compiled (e.g., Davies 1981, 1991; Werner \& Pont 2003), with some studies documenting black flies as the dominant dietary item of certain birds and fish (Gíslason 1985, Yoerg 1994, Robert \& Cloutier 2001). However, we have found only one reference to a carnivorous plant capturing black flies: about $0.8 \%$ of the total prey in one population of the Nearctic pitcher plant Sarracenia purpurea L. consisted of black flies (Cresswell 1991).

A common group of carnivorous plants in the boreal environment is the genus Pinguicula, consisting of three species in northern Scandinavia. The plants are perennial geophytes with one or a few flower stalks and a basal rosette usually of 28 leaves, each $2-5 \mathrm{~cm}$ long, bearing an upper glandular surface capable of capturing and di- 
Figure 1. Pinguicula vulgaris in northern Sweden, 15 June 2003, with adult black flies stuck to the adhesive surface of the leaves; the majority of black flies are beneath the curled leaf margins.

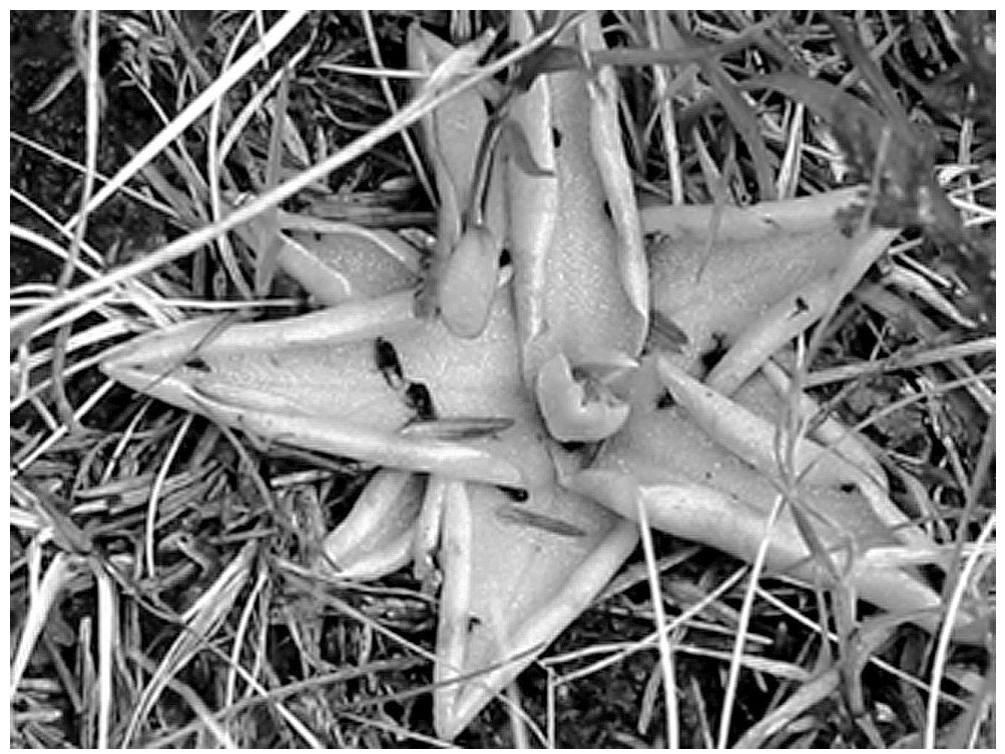

gesting arthropods (Karlsson et al. 1996). Prey, typically small arthropods, contribute significant amounts of nitrogen and phosphorous to Pinguicula and increase plant-nutrient uptake from the soil, enhancing fitness characters such as seed production and survival (Karlsson et al. 1996). Plants can obtain nearly all of the necessary nitrogen and phosphorous from their prey (Karlsson et al. 1994). Here we document the first report of black flies captured by carnivorous plants (Pinguicula vulgaris L.) in the boreal region.

\section{Material and methods}

We recorded the arthropods captured by $P$. vulgaris beside a stream (Skattån) ca. $600 \mathrm{~m}$ below its origin from a natural lake (Skatträsket) in Sweden (Swedish grid reference [x y]: 16622 72556) on 15 June 2003. Plants were sampled along an approximately $90-\mathrm{m}$ stretch of stream bank, within 1.2-2.1 $\mathrm{m}$ of the stream margin. We removed all macroscopic arthropods, by hand, from five groups of five plants each, for a total of 25 plants, each plant with $4-9$ (mean $5.9 \pm 0.34 \mathrm{~S}$. E.) leaves but without flowers. Mites were not sampled because some of them might inhabit the leaves (Karlsson et al. 1994). At the time of sampling, air temperature was $12.0^{\circ} \mathrm{C}$, water temper- ature $13.2^{\circ} \mathrm{C}$, conductivity $17 \mu \mathrm{S} / \mathrm{cm}, \mathrm{pH} 6.85$, and stream width $2.5 \mathrm{~m}$. We also collected larval black flies from the stream adjacent to the plants. All black flies were identified to the lowest taxonomic level, typically the species, whereas nonsimuliid taxa were identified to family. Voucher specimens of adult black flies are deposited in the Clemson University Arthropod Collection, Clemson, South Carolina.

\section{Results and discussion}

From 25 plants, we collected 915 arthropods representing 22 families (Table 1). The majority $(96.9 \%)$ of these arthropods were winged. Although our study was limited in space and time, a clear pattern emerged: captured prey were dominated by nematocerous Diptera $(94.6 \%)$, particularly the family Simuliidae $(84.7 \%)$. Our data agree with those of previous reports from northern Sweden that show a preponderance of nematocerous Diptera captured by $P$. vulgaris. However, our data do not mirror the high percentage of Collembola previously reported (Karlsson et al. 1994). Diptera also are the dominant prey captured by additional species of Pinguicula in other regions of the world (Zamora 1990, Antor \& Garcia 1994, Alcalá \& Domínguez 2003).

Nearly $98 \%$ of the captured black flies in our 
Table 1. Arthropods ( $n=915$ ) captured by Pinguicula vulgaris beside a stream (Skattån) in northern Sweden, 15 June 2003 , listed alphabetically by order and within order.

\begin{tabular}{|c|c|c|c|c|c|}
\hline Taxon & Larvae & Males & Females & Unknown & $\%$ of total \\
\hline \multicolumn{6}{|l|}{ Araneae } \\
\hline Linyphiidae & - & 3 & - & - & 0.3 \\
\hline \multicolumn{6}{|l|}{ Coleoptera } \\
\hline Staphylinidae & 1 & - & - & - & 0.1 \\
\hline \multicolumn{6}{|l|}{ Collembola } \\
\hline Entomobryidae & - & - & - & 6 & 0.7 \\
\hline Hypogastruridae & - & - & - & 1 & 0.1 \\
\hline Isotomidae & - & - & - & 11 & 1.2 \\
\hline \multicolumn{6}{|l|}{ Diptera } \\
\hline Ceratopogonidae & - & - & 2 & - & 0.2 \\
\hline Chironomidae & - & 4 & 19 & - & 2.5 \\
\hline Chloropidae & - & - & 1 & - & 0.1 \\
\hline Empididae & - & - & 1 & - & 0.1 \\
\hline Phoridae & _- & - & 1 & - & 0.1 \\
\hline Sciaridae & - & 29 & 40 & - & 7.5 \\
\hline Simuliidae & _- & 647 & 128 & - & 84.7 \\
\hline \multicolumn{6}{|l|}{ Hemiptera } \\
\hline Aphididae & - & - & 1 & - & 0.1 \\
\hline Cicadellidae & 7 & - & - & - & 0.7 \\
\hline Psyllidae & - & 1 & - & - & 0.1 \\
\hline \multicolumn{6}{|l|}{ Hymenoptera } \\
\hline Braconidae & - & 1 & - & - & 0.1 \\
\hline Ceraphronidae & - & 1 & - & - & 0.1 \\
\hline Formicidae & - & - & 2 (workers) & - & 0.2 \\
\hline Scelionidae & _ & 3 & -100 & _ & 0.3 \\
\hline \multicolumn{6}{|l|}{ Lepidoptera } \\
\hline Coleophoridae & - & 1 & - & - & 0.1 \\
\hline \multicolumn{6}{|l|}{ Plecoptera } \\
\hline Nemouridae & - & 1 & - & - & 0.1 \\
\hline \multicolumn{6}{|l|}{ Trichoptera } \\
\hline Hydroptilidae & - & - & 3 & - & 0.3 \\
\hline
\end{tabular}

study consisted of two species in the genus Cnephia, viz. C. eremites Shewell and C. pallipes (Fries). These species also were dominant (88.1\%) among larval black flies in the adjacent stream. Each cluster of five plants had a mean of 155 ( \pm 25.4 S. E.) black flies, with as many as 24 individuals per leaf. The preponderance of the genus Cnephia among the captured arthropods reflects the bionomics of these flies. Both species of Cnephia are common in the boreal regions of the world, where they breed in large populations at the outfalls of natural lakes and artificial impoundments. After emerging from the pupae, they concentrate their activities at the natal site. Females are obligatorily autogenous (i.e., the mouthparts are not adapted for blood feeding); they, therefore, do not need to disperse from the natal sites for blood meals, but instead remain near the stream, searching for oviposition sites, although flights for sugar meals might occur. Of 124 captured females, 8 carried chorionated eggs, 13 had immature eggs, and the remainder were devoid of eggs, suggesting that they had deposited their eggs before capture or that the immature eggs and fat body had been digested by the plants. Males search for and couple with females on the ground, rather than in the more typical aerial mating swarms (Adler et al. 2004). A population of Cnephia has developed in the Skattån stream since at least 1993; the adults emerge during June when $P$. vulgaris is actively growing. We do not know, however, the influence of Pinguicula predation, if any, on the population of the two species of Cnephia. 
Table 2. Simuliid adults (males and females) captured by streamside Pinguicula vulgaris, plus simuliid larvae collected in the adjacent stream (Skattån) in northern Sweden, 15 June 2003; species are listed alphabetically.

\begin{tabular}{lccc}
\hline Species $^{\mathrm{A}}$ & Males & Females & Larvae \\
\hline $\begin{array}{l}\text { Cnephia eremites } \\
\quad \text { Shewell }\end{array}$ & 635 & $\mathrm{x}^{\mathrm{B}}$ & 110 \\
$\begin{array}{c}\text { Cnephia pallipes } \\
\quad \text { (Fries) }\end{array}$ & 3 & $\mathrm{x}^{\mathrm{B}}$ & 46 \\
$\begin{array}{c}\text { Simulium paramorsitans } \\
\quad \text { Rubtsov }\end{array}$ & 5 & 1 & 17 \\
$\begin{array}{c}\text { Simulium truncatum } \\
\quad \text { Lundström) }\end{array}$ & 1 & 2 & 1 \\
$\begin{array}{c}\text { Simulium vernum } \\
\quad \text { Macquart }\end{array}$ & 0 & 0 & 3 \\
$\begin{array}{c}\text { Stegopterna trigonium } \\
\quad \text { (Lundström) }\end{array}$ & 3 & 1 & 0 \\
\hline
\end{tabular}

A One male and two females of the genus Cnephia were infected with mermithid nematodes.

${ }^{B}$ Species-level characters are not available to identify the 124 females of Cnephia.

Other than two ant workers and one stonefly adult, black flies were the largest organisms captured by the plants in our study. These black flies are nearly the same size as Drosophila flies that have been fed experimentally to $P$. vulgaris. Nitrogen from captured Drosophila is allocated to plant reproductive organs and winter buds and also increases the uptake of nitrogen from the soil; however, only about $29-42 \%$ of the nitrogen in Drosophila is exploited, which is less than the stimulated root uptake from the soil (Hanslin \& Karlsson 1996). Hanslin and Karlsson (1996) speculated that prey smaller than Drosophila might allow more complete digestion and assimilation of prey. Too many prey, however, could negatively affect photosynthetic abilities (Karlsson et al. 1996) or perhaps provide substrate for bacterial and fungal growth harmful to the plant. Studies are needed to determine the nutritive value of black flies, measured as an increase in plant fitness, and the possible costs associated with increased numbers of prey.

The male-biased sex ratio $(5: 1)$ of the captured Cnephia might reflect (1) the possibility that males are more active than females on stream banks and, therefore, more likely to be captured, (2) a characteristic sex ratio of the species, as in the obligatorily autogenous Nearctic Cnephia dacotensis (Dyar \& Shannon) in which mating occurs on the ground and males outnumber females by more than 3 to 1 (Back \& Harper 1979), (3) a greater probability of escape by females, as recorded for spider-web captures of some Nearctic black flies (Adler et al. 1983), or (4) a temporal sampling bias; most black flies are protandrous (i.e., males emerge before females), and we might have collected the flies before the peak of female emergence.

The flow of organisms and energy between aquatic and terrestrial systems, represented here by the interactions of terrestrial carnivorous plants and their aquatic-derived prey, provide a model system in landscape ecology (cf. Nakano $\&$ Murakami 2001). The capture of black flies by $P$. vulgaris, although presumably opportunistic, further illustrates the breadth of possible interactions between black flies and other biota of the boreal region.

Acknowledgements. We thank P. S. Karlsson for identifying the Pinguicula, and C. E. Beard, J. C. Morse, and A. G. Wheeler, Jr. for reviewing the manuscript. This study was supported in part by the Swedish Taxonomy Initiative and the CSREES/USDA, under project number SC-1700125. This is Technical Contribution No. 4943 of the Clemson University Experiment Station. The Swedish Research Council for Environment, Agricultural Sciences, and Spatial Planning (FORMAS) provided support for BM.

\section{References}

Adler, P. H., Currie, D. C. \& Wood, D. M. 2004. The black flies (Simuliidae) of North America. - Cornell University Press, Ithaca, NY. 941 pp. + 24 color plates.

Adler, P. H., Kim, K. C. \& Light, R. W. 1983: Flight patterns of the Simulium vittatum (Diptera: Simuliidae) complex over a stream. - Environmental Entomology 12: 232-236.

Alcalá, R. E. \& Domínguez, C. A. 2003. Patterns of prey capture and prey availability among populations of the carnivorous plant Pinguicula moranensis (Lentibulariaceae) along an environmental gradient. American Journal of Botany 90: 1341-1348.

Antor, R. J. \& Garcia, M. B. 1994. Prey capture by a carnivorous plant with hanging adhesive traps: Pinguicula longifolia. - American Midland Naturalist 131: 128-135.

Back, C. \& Harper, P. P. 1979: Succession saisonnière, émergence, voltinisme, et répartition de mouches noires des Laurentides (Diptera; Simuliidae). - Cana- 
dian Journal of Zoology 57: 627-639.

Bonan, G. B. \& Shugart, H. H. 1989: Environmental factors and ecological processes in boreal forests. - Annual Review of Ecology and Systematics 20: 1-28.

Cresswell, J. E. 1991: Capture rates and composition of insect prey of the pitcher plant Sarracenia purpurea. American Midland Naturalist 125: 1-9.

Davies, D. M. 1981: Predators upon blackflies. - In: Laird, M. (ed.), Blackflies: the future for biological methods in integrated control: 139-158. Academic Press, New York. 399 pp.

Davies, D. M. 1991: Additional records of predators upon black flies (Simuliidae: Diptera). - Bulletin of the Society for Vector Ecology 16: 256-268.

Gíslason, G. M., 1985: The life cycle and production of Simulium vittatum Zett. in the River Laxá, North-east Iceland. - Verhandlungen der Internationalen Vereinigung für theoretische und angewandte Limnologie 22: 3281-3287.

Hanslin, H. M. \& Karlsson, P. S. 1996: Nitrogen uptake from prey and substrate as affected by prey capture level and plant reproductive status in four carnivorous plant species. - Oecologia 106: 370-375.

Karlsson, P. S., Thorén, L. M. \& Hanslin, H. M. 1994: Prey capture by three Pinguicula species in a subarctic environment. — Oecologia 99: 188-193.

Karlsson, P. S., Svensson, B. M. \& Carlsson, B. A. 1996: The significance of carnivory for three Pinguicula species in a subarctic environment. - Ecological Bulletins 45: 115-120.

Malmqvist, B., Adler, P. H., Kuusela, K., Merritt, R. W. \& Wotton, R. S. 2004: Black flies in the boreal biome: key organisms in both terrestrial and aquatic environments. A review. - Écoscience 11: 187-200.

Nakano, S. \& Murakami, M. 2001. Reciprocal subsidies: dynamic interdependence between terrestrial and aquatic food webs. - Proceedings of the National Academy of Sciences USA 98: 166-170.

Robert, M. \& Cloutier, L. 2001: Summer food habits of Harlequin Ducks in eastern North America. — Wilson Bulletin 113: 78-84.

Werner, D. \& Pont, A. C. 2003: Dipteran predators of simuliid blackflies: a worldwide review. - Medical and Veterinary Entomology 17: 115-132.

Wotton, R. S., Malmqvist, B., Muotka, T. \& Larsson, K. 1998: Fecal pellets from a dense aggregation of suspension-feeders in a stream: an example of ecosystem engineering. - Limnology and Oceanography 43: 719-725.

Yoerg, S. I. 1994: Development of foraging behaviour in the Eurasian dipper, Cinclus cinclus, from fledging until dispersal. - Animal Behavior 47: 577-588.

Zamora, R. 1990: The feeding ecology of a carnivorous plant (Pinguicula nevadense): prey analysis and capture constraints. - Oecologia 84: 376-379. 